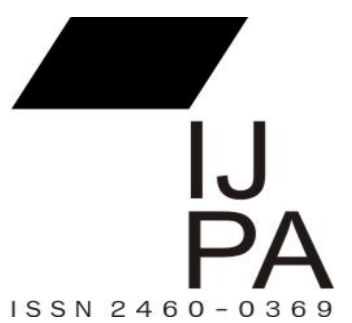

ISSN $2460-0369$

\section{MANAJEMEN PELAYANAN PENANGGULANGAN KASUS HIV-AIDS DI KOTA YOGYAKARTA}

\author{
Gerry Katon Mahendra \\ (Administrasi Publik UNISA Yogyakarta) \\ Hari Akbar Sugiantoro \\ (Komunikasi UNISA Yogyakarta) \\ Universitas 'Aisyiyah Yogyakarta \\ email: gerrykatonvw@gmail.com
}

\begin{abstract}
The high number of HIV AIDS cases in the city of Yogyakarta requires the authorities to take appropriate action so that the spread of this virus can be minimized. KPAD has important duties and positions to provide maximum services for vulnerable community groups infected with the virus. based on the results of research, public service management applied in KPA Kota Yogyakarta is more coordinative and indirect service. They focus on maximizing the role of OPDs, NGOs, and communities in order to reach out to vulnerable communities who are infected with the HIV AIDS virus. This measure is effectively marked by the multitude of coordination activities between institutions so as to identify HIV sufferers from the early stages and provide the right follow-up.

Keywords : Public Service, National AIDS Commission, HIV AIDS
\end{abstract}

\begin{abstract}
ABSTRAK : Tingginya kasus HIV AIDS di Kota Yogyakarta menuntut pihak berwenang melakukan tindakan yang tepat agar penyebaran virus ini dapat diminimalisir. KPAD memiliki tugas dan posisi penting guna memberikan pelayanan maksimal bagi kelompok masyarakat rentan terinfeksi virus tersebut. berdasarkan hasil penelitian, manajemen pelayanan publik yang diterapkan di KPA Kota Yogyakarta lebih bersifat koordinatif dan pelayanan tidak langsung. Mereka fokus pada memaksimalkan peran OPD, LSM, dan masyarakat guna menjangkau kelompok masyarakat yang rentan terinfeksi virus HIV AIDS. Langkah ini dinilai efektif ditandai dengan banyaknya kegiatan koordinatif antar lembaga sehingga mampu mengidentifikasi penderita HIV dari tahap awal dan memberikan pelayaan lanjutan yang tepat.

Kata Kunci : Pelayanan Publik, Komisi Penanggulangan AIDS, HIV AIDS
\end{abstract}




\section{PENDAHULUAN}

Kesehatan masyarakat merupakan salah satu faktor penting dalam upaya membangun Negara. Pemerintah mengeluarkan berbagai upaya dan kebijakan guna menjamin kesehatan masyarakatnya. Namun terkadang tidak dapat dipungkiri bahawa masih terdapat beberapa kasus penyakit yang sulit untuk ditangani oleh pemerintah. Salah satu penyakit tersebut adalah HIV-AIDS. Kasus Human Immunodeficiency Virus dan Acquired Immune Deficiency Syndrome (HIV-AIDS) di Indonesia mengalami tren yang cenderung meningkat dari tahun ketahun. Menurut data Kemenkes sebagaimana dilansir oleh Spiritia.or.id (2016) sejak tahun 2005 jumlah kasus HIV yang dilaporkan sebanyak 859, tahun 2006 (7.195), tahun 2007 (6.048), tahun 2008 (10.362), tahun 2009 (9.793), tahun 2010 (21.591), tahun 2011 (21.031), tahun 2012 (21.511), tahun 2013 (29.037), tahun 2014 (32.711), tahun 2015 (30.935), dan tahun 2016 (41.250).

Jumlah kumulatif infeksi HIV yang dilaporkan sampai dengan Desember 2016 sebanyak 232.323 kasus. Sedangkan untuk kasus AIDS sejak tahun 2005 jumlah AIDS dilaporkan sebanyak 5.239, tahun 2006 (3.680), tahun 2007 (4.828), tahun 2008 (5.298), tahun 2009 (6.744), tahun 2010 (7.470), tahun 2011 (8.279), tahun 2012 (10.862), tahun2013 (11.741), tahun 2014 (7.963), tahun 2015 (7.185), dan 2016 (7.491). Jumlah kumulatif AIDS dari tahun 1987 sampai dengan Desember 2016 sebanyak 86.780 orang.

Dengan semakin meningkatnya kasus HIV-AIDS di Indonesia, sudah seharusnya pemerintah pusat dan pemerintah daerah melakukan upaya-upaya preventif guna meminimalisir kemungkinan munculnya penderita HIV-AIDS baru. Wilayah Kota Yogyakarta sebagai salah satu kota wisata, kota pendidikan dan menjadi tempat berkumpulnya para anak muda usia produktif (mahasiswa/mahasiswi) dari seluruh Indonesia tentu mengalami kerentanan cukup tinggi terhadap virus HIVAIDS. Dengan tupoksi yang sedemikian rupa, jelas bahwa KPAD Kota Yogyakarta harus mampu menekan, meminimalisir atau bahkan menghapuskan penyebaran kasus HIV di Kota Yogyakarta. KPAD Kota Yogyakarta pada tahun 2015 mendapatkan 
penghargaan dari KPA Pusat sebagai KPAD tingkat Kabuapten/Kota terbaik se-Jawa Tengah.

Prestasi ini didapatkan berkat penilaian keunggulan kinerja pada tiga indikator utama yakni bidang kelembagaan, bidang program, dan bidang administrasi. Prestasi tersebut tentu saja membanggakan bagi KPAD Kota Yogyakarta. Namun hal tersebut dirasa kurang relevan apabila melihat data kasus HIV AIDS di Kota Yogyakarta yang justru semakin meningkat dari tahun ketahun. Data Komisi Penanggulangan AIDS (KPA) Kota Yogyakarta mencatat hingga Maret 2015 mencatat terdapat 831 kasus HIV-AIDS. Jumlah tersebut meningkat cukup signifikan dari jumlah total kasus di 2014 sebanyak 802 kasus dan 2013 ada 677 kasus serta pada 2012 tercatat 566 kasus. Dari data tersebut, sebanyak 37 persen diantaranya menjangkiti masyarakat usia produktif (Republika, 2015).

Berdasarkan data dan fakta tersebut, dapat disimpulkan bahwa masih terdapat kekurangan dalam hal pelayanan penanganan kasus HIV AIDS di Kota Yogyakarta. Hal ini kemudian menarik untuk ditindaklanjuti menjadi rencana penelitian untuk melihat lebih mendalam mengenai manajemen pelayanan yang dilakukan dalam penanganan kasus HIV-AIDS di Kota Yogyakarta. Penulis berencana melakukan penelitian dengan judul "Manajemen Pelayanan Penanggulangan Kasus HIV-AIDS di Kota Yogyakarta Tahun 2017". Penulis akan melihat bagaimana pelaksanaan pelayanan penanganan penanggulanan HIV-AIDS secara menyeluruh mulai dari tahapan pendidikan/sosialisasi, pencegahan, hingga penanganan tindak lanjut bagi para penderita HIV-AIDS.

\section{TINJAUAN PUSTAKA}

Penelitian yang dilakukan oleh Joko Irwanto (2010) dengan judul Manajemen Pelayanan Penanggulangan Hiv/Aids Pada Komisi Penanggulangan Aids (Kpa) Kota Surakarta penelitian tersebut bertujuan menilai bagaimana manajemen pelayanan penanggulangan HIV/AIDS pada Komisi penanggulangan AIDS (KPA) Kota Surakarta. Mengacu pada teori segitiga pelayanan, komponen dari segitiga pelayanan meliputi strategi pelayanan (service strategy), sumber daya pemberi pelayanan (service people) dan sistem pelayanan (service system). 
Hasil penelitian membuktikan bahwa dari ketiga strategi pelayanan tersebut dapat diketahui bahwa strategi pelayanan yang dilakukan KPA Kota Surakarta telah berjalan dengan baik dan melalui program-program yang terencana dan terarah, sumber daya pemberi pelayanan dan sistem pelayanan sudah cukup baik meskipun masih terdapat beberapa kekurangan atau keterbatasan namun pihak KPA berusaha untuk meminimalisasi dengan merespon apa yang menjadi keluhan-keluhan dari masyarakat melalui sistem pengaduan yang telah disediakan, sehingga pelayanan kesehatan yang diberikan sesuai dengan apa yang diharapkan oleh masyarakat.

KPA Kota surakarta hendaknya lebih bisa menjangkau orang-orang yang beresiko tinggi yang berada dipinggiran kota. KPA Kota Surakarta juga harus mampu mengupayakan sumber dana dan tidak tergantung terhadap bantuan dari Global Fund. KPA Kota Surakarta juga harus mampu meningkatkan koordinasi dan peningkatan kualitas pemberi pelayanan yang langsung berhubungan dengan klien. Semua itu diharapkan agar KPA Kota Surakarta mampu meningkatkan kualitas pelayanannya.

Penelitian yang dilakukan oleh Mia Auliani (2016) berjudul Strategi Komisi Penanggulangan AIDS Kota Samarinda Dalam Pencegahan HIV/AIDS. Penelitian tersebut bertujuan untuk mengetahui dan mendiskripsikan Strategi Komisi Penanggulangan AIDS dalam melaksanakan Pencegahan HIV/AIDS Di Kota Samarinda dan untuk mengetahui dan mendeskripsikan apa saja faktor pendukung dan penghambat Strategi Komisi Penanggulangan HIV/AIDS (KPA) Kota Samarinda dalam melaksanakan pencegahan penularan HIV/AIDS di Kota Samarinda.

Hasil penelitian yang diperoleh menunjukan bahwa strategi yang di laksanakan oleh Komisi penanggulangan AIDS (KPA) dalam melakukan pencegahan HIV dan AIDS di Kota Samarinda dapat di lihat dari strategi KPA yaitu Sosialisasi kepada masyarakat agar mengetahui cara pencegahan dan penularan penyakit ini, selanjutnya strategi KPA dengan melakukan layanan komunikasi publik agar masyarakat dapat mengetahui dengan mudah perkembangan HIV/AIDS di Kota Ssamarinda dan Kemudian strategi KPA melakukan koordinasi dengan dinas dan instansi terkait melalui rapat evaluasi, pertemuan kemitraan dan melakukan 
perencanaan untuk memberikan penyuluhan kepada masyarakat umum yang rawan akan penyebaran HIV dan AIDS.

- Berdasarkan beberapa penelitian terdahulu, diketahui bahwa rencana penelitian ini tidak memiliki kesamaan persis dengan penelitian sebelumnya. Rencana penelitian ini akan lebih berfokus pada manajemen pelayanan pengananan kasus AIDS di Kota Yogyakarta selama tahun 2017. Tujuan dari penelitian ini adalah untuk menggali lebih dalam mengenai pengelolaan penanganan AIDS dari perspektif pemberi layanan dan pengguna layanan.

\section{Manajemen}

Gulick dalam Wijayanti (2008) mendefinisikan manajemen sebagai suatu bidang ilmu pengetahuan (science) yang berusaha secara sistematis untuk memahami mengapa dan bagaimana manusia bekerja bersama-sama untuk mencapai tujuan dan membuat sistem ini lebih bermanfaat bagi kemanusiaan.

Menurut Terry (2010), fungsi manajemen dapat dibagi menjadi empat bagian, yakni planning (perencanaan), organizing (pengorganisasian), actuating (pelaksanaan), dan controlling (pengawasan).

Berdasarkan beberapa pendapat diatas dapat disimpulkan bahwa manajemen merupakan ilmu dan seni yang mempelajari dan mempraktekkan proses kerjasama dalam suatu lembaga organisasi dengan mencanangkan target atau tujuan-tujuan tertentu. Proses kerjasama tersebut mencakup perencanaan tujuan, pengorganisasian SDM, pelaksanaan kegiatan, dan pengawasan secara menyeluruh.

\section{Pelayanan Publik}

Pelayanan publik menurut Sinambela dalam Harbani Pasolong (2013) adalah sebagai setiap kegiatan yang dilakukan oleh pemerintah terhadap sejumlah manusia yang memiliki setiap kegiatan yang menguntungkan dalam suatu kumpulan atau kesatuan, dan menawarkan kepuasan meskipun hasilnya tidak terikat pada suatu produk secara fisik.

Standar pelayanan publik menurut Keputusan Menteri PAN Nomor 63/KEP/ M.PAN/7/ 2003 dalam Hardiansyah (2011) sekurang- kurangnya meliputi :

a. Prosedur pelayanan; 
b. Waktu penyelesaian;

c. Biaya pelayanan;

d. Produk pelayanan;

e. Sarana dan prasarana;

f. Kompetensi petugas pelayanan.

Berdasarkan pendapat diatas dapat disimpulkan bahwa pelayanan publik merupakan kegiatan pelayanan jasa maupun barang publik yang dilakukan oleh lembaga publik / pemerintah berlandaskan peraturan perundang-undangan yang berlaku dan standar baku demi kepentingan masyarakat umum.

\section{Manajemen Pelayanan Publik}

Menurut Ratminto dan Atik Septi Winarsih (2005) manajemen pelayanan dapat diartikan sebagai suatu proses penerapan ilmu dan rencana, mengimplementasikan rencana, mengoordinasikan, dan menyelesaikan aktivitasaktivitas pelayanan demi tercapainya tujuan pelayanan.

\section{Gambar}

Manajemen Pelayanan Publik

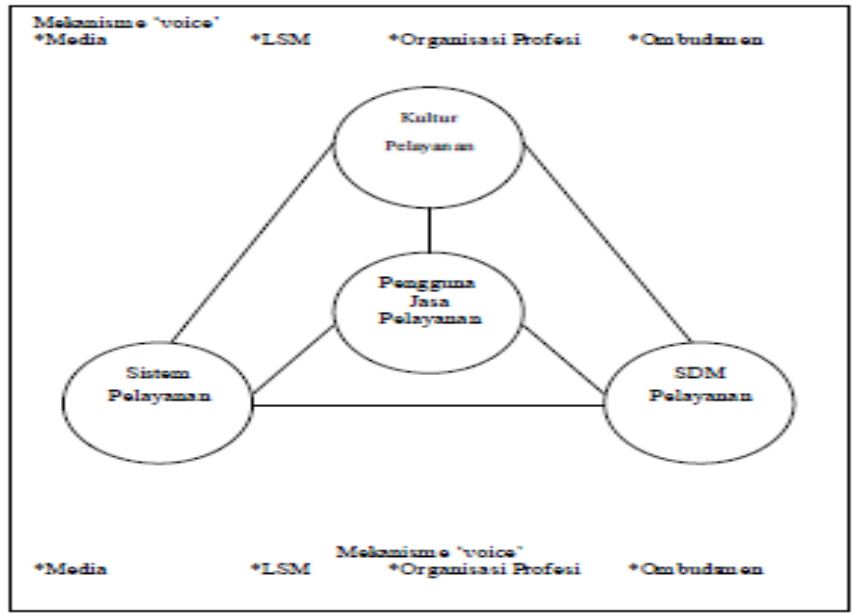

Sumber : Ratminto dan Atik (2005)

Manajemen pelayanan dapat dilaksanakan apabila pengguna jasa pelayanan (masyarakat) menjadi pihak yang diprioritaskan. Dalam manajemen pelayanan, posisi pengguna jasa harus terjamin dan berhak mendapatkan hal-hal sebagai berikut : 
a. Sistem pelayanan yang mengutamakan kepentingan masyarakat, khususnya pengguna jasa;

b. Kultur pelayanan dalam organisasi penyelenggara pelayanan;

c. Sumber daya manusia yang berorientasi pada kepentingan pengguna jasa.

Pengguna jasa pelayanan menurut Vincent Gaspersz dalam Harbani Pasolong (2013) adalah mereka yang secara langsung maupun tidak langsung menggunakan jenis-jenis pelayanan publik atau mereka yang secara langsung maupun tidak langsung terkena dampak dari kebijakan-kebijakan organisasi publik. Organisasi publik memiliki pelanggan yang dapat dikategorikan sebagai pelanggan internal dan pelanggan eksternal, yaitu :

a. Pelanggan internal (internal costumers) mencakup unit-unit atau pegawai dalam suatu dalam suatu organisasi publik yang bekerja tergantung pada unit atau pegawai yang lain dalam organisasi yang sama.

b. Pelanggan eksternal (external costumers) mencakup pengguna produk (barang dan/ atau jasa) dari organisasi publik.

Manajemen pelayanan publik dalam konteks penelitian kali ini adalah menganalisis kemampuan pemerintah dalam melakukan pengelolaan penanganan kasus HIV-AIDS, menganalisis program-program yang dilakukan oleh pemerintah dalam upaya menangani kasus HIV-AIDS, dan kultur pelayanan yang diberikan pemerintah (KPAD) dalam upaya menangani kasus HIV-AIDS di Kota Yogyakarta pada tahun 2017.

\section{HIV-AIDS}

Human Immunodeficiency Virus (HIV) merupakan retrovirus yaitu virus yang mempunyai enzim revese transkriptase yang memungkinkan virus ini untuk mengubah informasi genetiknya yang berada dalam ribonukleat (RNA) ke dalam bentuk deoksibonukleat (DNA) (Widyanto dan Triwibowo, 2013). Hasil dari perubahan ini akan diintegrasikan ke dalam informasi genetik sel limfosit yang diserang kemudian memanfaatkan mekanisme sel limfosit untuk menggandakan dirinya menjadi virus baru yang memiliki ciri seperti HIV (Widyanto dan Triwibowo, 2013). 
Berdasarkan beberapa pendapat diatas dapat disimpulkan bahwa HIV-AIDS merupakan gejala penyakit yang timbul karena turunnya kekebalan tubuh. AIDS disebabkan oleh infeksi virus HIV. AIDS merupakan penyakit yang didapatkan akibat dari tindakan-tindakan yang menyimpang seperti, penyalahgunaan narkoba dan perilaku seks yang tidak aman. Penderita HIV-AIDS kerapkali divonis tidak memiliki harapan hidup lama karena sampai saat ini obat yang dikhususkan untuk pengobatan penyakit tersebut belum ditemukan. Selain itu juga, para penderita HIVAIDS kerap kali mendapat diskriminasi / hukuman sosial dari masyarakat karena dianggap memiliki perilaku menyimpang dari norma-norma yang berlaku.

Mengingat begitu rentannya para penderita HIV-AIDS baik dari segi kesehatan dan juga sosial, maka peran pemerintah sangat penting untuk menjamin keberlangsungan hidup para penderita tersebut. Pemerintah daerah kota Yogyakarta dalam hal ini KPAD Kota Yogyakarta memiliki peran penting dalam upaya memberikan pelayanan menyeluruh bagi para penderita HIV-AIDS.

Kerangka berfikir yang digunakan mengacu pada model segitiga pelayanan. Dimana dalam model segitiga tersebut terdapat beberapa unsur yang harus dijalankan, yaitu : a). budaya pelayanan; b). sistem pelayanan; c). SDM pelayanan. Ratminto dan Atik (2005). Ketiga unsur tersebut kemudian dikembangkan untuk menciptakan proses manajerial yang baik (good managerial). Output dari hal tersebut tentu saja bertujuan memenuhi kebutuhan pengguna layanan.

\section{METODE PENELITIAN}

Rancangan penelitian merupakan rencana seistematika penelitian mencakup hal-hal yang akan dilakukan peneliti mulai dari memilih jenis penelitian, pengambilan data, verifikasi data, analsisis data dan kesimpulan penelitian. Penelitian ini menggunakan pendekatan deskriptif kualitatif. Menurut Sugiyono (2012) penelitian deskriptif merupakan penelitian yang dilakukan untuk mengetahui nilai variabel mandiri, baik satu variabel atau lebih (independen) tanpa membuat perbandingan, atau menghubungkan dengan variabel yang lain.

Dalam penelitian ini subjek penelitian / informan merupakan pihak yang berkompeten dan mengetahui permasalahan penelitian. Penentuan informan dalam 
penelitian kualitatif berfungsi untuk mendapatkan informasi yang maksimum dengan mempertimbangkan hal-hal tertentu seperti dianggap paling tahu tentang apa yang diharapkan atau mengehatui secara jelas yang dapat memudahkan peneliti (Sugiyono, 2013).

Wawancara (interview) adalah cara-cara untuk memperoleh data dengan berhadapan langsung, bercakap-cakap, baik antara individu dengan individu maupun individu dengan kelompok. Wawancara melibatkan dua komponen, pewawancara yaitu peneliti itu sendiri dan orang yang diwawancarai. (Ratna, 2010). Alat yang digunakan dalam melakukan tahapan wawancara adalah alat rekam (recorder), buku catatan, dan alat tulis.

Dokumen menurut Sugiyono (2009) merupakan catatan peristiwa yang sudah berlalu. Dalam penelitian ini, dokumentasi merupakan bagian dari data sekunder yang dibutuhkan oleh peneliti. Data dokumen dalam penelitian ini berupa dokumentasi arsip, catatan, dan foto kegiatan manajemen pelayanan penanganan kasus HIV-AIDS di KPA Kota Yogyakarta.

Teknik analisis data dalam penelitian ini merujuk pada teori yang dikemukakan oleh Huberman dan Miles. Huberman dan Miles seperti dikutip Idrus (2009) mengajukan model analisis data yang disebut dengan model interaktif. Model interaktif terdiri dari tiga hal utama, yaitu:

Reduksi data merupakan langkah awal dalam menganalisa data dalam penelitian ini. Dalam penelitian ini, aspek-aspek yang direduksi adalah hasil wawancara maupun dokumentasi terkait dengan manajemen pelayanan penanganan kasus HIV AIDS di Kota Yogyakarta. Penyajian data (display) merupakan tahapan kedua dari tiga tahapan aktivitas menganalisa data dalam penelitian kualitatif. Hal yang penulis lakukan dalam proses penyajian data pada penelitian ini adalah penulis menggambarkan secara umum hasil penelitian dimulai dari lokasi penelitian dan deskripsi objek penelitian. Penarikan kesimpulan dan verifikasi adalah bagian ketiga dan merupakan unsur penting dalam teknik analisa data pada penelitian. Dari berbagai aktivitas yang telah dilakukan sebelumnya, penulis membuat kesimpulan berdasarkan data-data yang telah dikumpulkan. 
Etika ialah suatu ilmu yang membicarakan masalah perbuatan atau tingkah laku manusia, mana yang dapat dinilai baik dan mana yang dapat dinilai buruk dengan memperlihatkan amal perbuatan manusia sejauh yang dapat dicerna akal pikiran (Rahmaniyah, 2010). Dalam penelitian ini, peneliti menjunjung tinggi etika / sikap perbuatan untuk menghormati informan sebagai subjek penelitian, menilai dan menganalisis data penelitian kualitatif dengan mengedepankan prinsip keadilan dan objektivitas serta mempublikasikan manfaat yang dihasilkan dari penelitian tersebut.

\section{PEMBAHASAN}

Dasar pembentukan Komisi Penanggulangan AIDS di Kota Yogyakarta adalah Peraturan Walikota Yogyakarta Nomor 106 Tahun 2016 tentang penanggulangan HIV dan AIDS. Komisi Penanggulangan AIDS (KPA) Kota Yogyakarta merupakan lembaga pemerintahan yang melaksanakan berbagai upaya pencegahan dan penanggulangan HIV dan AIDS di Kota Yogyakarta. KPA Kota Yogyakarta terletak Jalan Kenari No.56, Muja Muju, Umbulharjo, Kota Yogyakarta, Daerah Istimewa Yogyakarta 55165. Adapun struktur organisasi Komisi Penanggulangan AIDS (KPA) Kota Yogyakarta adalah sebagai berikut :

\section{Susunan Komisi Penanggulangan AIDS Kota Yogyakarta Periode $2012-2015$}

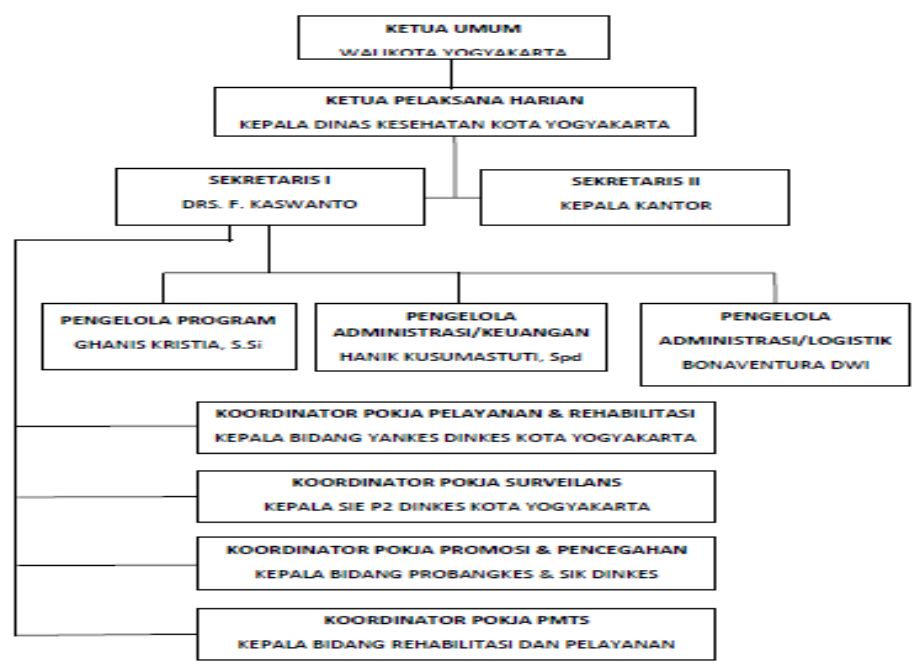

Sumber : KPA Kota Yogyakarta, 2018 
Berdasarkan hasil wawancara yang dilakukan oleh peneliti kepada pengurus Komisi Penanggulangan AIDS (KPA) Kota Yogyakarta terkait dengan manajemen pelayanan publik kepada masyarakat yang berpotensi terinfeksi HIV AIDS dan penderita HIV AIDS selama tahun 2017 didapatkan hasil sebagai berikut :

Komisi Penanggulangan AIDS merupakan lembaga yang dimiliki oleh pemerintah Indonesia dengan tugas utama untuk menanggulangi dan menangani kasus HIV AIDS. KPA memiliki perwakilan di daerah, sering disebut KPA Daerah, mulai tingkat Provinsi hingga Kabupaten/Kota. Daerah Istimewa Yogyakarta (DIY) yang notabene memiliki lima Kabupaten/Kota sudah memiliki KPA dimasing-masing wilayahnya. KPA Kota Yogyakarta, sebagai salah satu KPA yang ada di Kota Yogyakarta merupakan lembaga non struktural yang berada dilingkungan Pemerintah Kota Yogyakarta. Sekretariat KPA Kota Yogyakarta memiliki kepala (sekretaris) dengan kualifikasi mantan eselon II/mantan kepala dinas. Terkait dengan apakah terdapat kompetensi khusus bagi pegawai di KPA Kota Yogyakarta, jawabannya dapat dilihat berdasarkan data lapangan berikut. Pengelola program di KPA yang berasal dari S1 sains biologi. Kemudian pengelolaan keuangan dari pendidikan Kemudian pengelola logistik yakni terkait distribusi kondom kemudian pencatatan dan pelaporan untuk kondom dan juga jarum suntik juga berasal dari pendidikan akuntansi. Artinya, di KPA Kota Yogyakarta hanya bagian keuangan saja yang harus memiliki pendidikan/kualifikasi khusus.

KPA Kota Yogyakarta memiliki tugas utama yakni melakukan upaya koordinasi dengan Dinas/SKPD terkait, terutama Dinas Kesehatan Kota Yogyakarta terkait dengan penanganan dan penanggulangan AIDS di Kota Yogyakarta. Hal ini selaras dengan pendapat Terry (2010), dimana fungsi manajemen dalam suatu organisasi dapat dibagi menjadi empat bagian, yakni planning (perencanaan), organizing (pengorganisasian), actuating (pelaksanaan), dan controlling (pengawasan). KPA Kota Yogyakarta berdiri sejak tahun 2006 berdasarkan SK Wali Kota tentang pembentukan Komisi Penanggulangan AIDS Kota Yogyakarta. Sebagai lembaga non struktural yang lebih mengutamakan koordinasi tugas dengan Dinas 
terkait dan tidak terlalu menyentuh pada ranah kesehatan. Fokus KPA Kota Yogyakarta lebih kepada bidang pemberdayaan/pelayanan tidak secara langsung.

Spot utama penanggulan HIV AIDS di Kota Yogyakarta meliputi wilayah Pasar Kembang (wilayah pantauan utama) Dinas kesehatan rutin melakukan kegiatan serum survey untuk dites HIV dan juga sipilisnya. Beberapa spot yang kita selain pasar kembang itu misalnya dibelakang Stasiun Tugu, kompleks luar terminal Giwangan yang sudah tutup akhir tahun 2016 lalu, spot rawan homoseksual berada disekitar alun-alun (sekarang sudah ditutup), pengawasan saat ini difokuskan pada daerah cafe, mall, dan media sosial.

Berdasarkan data dilapangan, KPA Kota Yogyakarta sudah melatih warga peduli AIDS yang ditempatkan pada tiap kelurahan yang ada di Kota Yogyakarta. Pelayanan HIV AIDS dari ranah kesehatan tetap menjadi kewenangan Dinas Kesehatan Kota Yogyakarta beserta Unit Pelaksana Teknis (UPT) baik rumah sakit maupun lembaga kesehatan milik pemerintah yang lainnya.

Kegiatan yang berkaitan dengan pelayanan bagi pasin HIV AIDS dimulai dari tahapan pelayanan promosi dan pencegahan. Motto yang sering diusung oleh KPA Kota Yogyakarta adalah "temukan, obati, pertahankan". Temukan kasus HIV sedini mungkin, kemudian langsung diobati, dan pertahankan pengobatannya.

KPA Kota Yogyakarta juga menggandeng LSM yang concern dibidang penanggulangan HIV AIDS guna memberikan pelayanan. Kerjasama dan koordinasi dengan LSM dilakukan karena LSM dengan sumber daya yang ada dirasa mampu menjangkau warga maupun komunitas yang rentan terhadap penularan HIV AIDS. LSM memiliki peranan penting dan juga dapat dikatakan sebagai kepanjangan tangan dari KPA Kota Yogyakarta dalam proses pelayanan kepada pihak yang rentan penyebaran HIV AIDS. Untuk penjangkauan populasi kunci HIV dilakukan LSM Vesta, Yayasan Vesta Indonesia. Kemudian untuk yang pendampingan ODA dilakukan oleh LSM Yayasan Victory plus. Dalam hal ini, kelompok masyarakat ataupun komunitas yang dianggap rentan terhadap penularan HIV AIDS meliputi pekerja sex komersial (PSK), laki-laki yang berhubungan sex sesama jenis 
(homoseksual), waria, pecandu narkotika suntik, anak jalanan, dan komunitas lainnya.

LSM menjangkau populasi-populasi rentan di lokasi hotspotnya masingmasing uuntuk kemudian diberikan informasi mengenai HIVAIDS. Jika kemudian dari komunitas rentan tersebut terdapat anggotanya yang terindikasi secara umum mengidap/tertular HIV AIDS maka langkah selanjutnya yang harus dilakukan oleh LSM tersebut adalah merujuk ke lembaga kesehatan, baik rumah sakit umum maupun puskesmas untuk mendapatkan tindakan lebih lanjut (tes HIV sejak dini) dan juga melaporkan perkembangan data kepada KPA Kota Yogyakarta serta Dinas Kesehatan Kota Yogyakarta. Jika sudah masuk pada tahapan pemeriksaan (tes HIV) maka pelayanan tersebut sudah masuk dalam ranah pelyanan Dinas Kesehatan Kota Yogyakarta melalui UPT nya masing-masing.

Saat ini sudah terdapat total 17 puskesmas di Kota Yogyakarta yang dapat memberikan pelayanan tes HIV dan empat diantaranya sudah dapat memberikan pengobatan ARV bagi pasien. Menurut Vincent Gaspersz dalam Harbani Pasolong (2013) pengguna jasa pelayanan adalah mereka yang secara langsung maupun tidak langsung menggunakan jenis-jenis pelayanan publik atau mereka yang secara langsung maupun tidak langsung terkena dampak dari kebijakan-kebijakan organisasi publik. Dalam hal ini, pengguna jasa pelayanan publik adalah mereka yang terindikasi mengidap virus HIIV AIDS. Setiap anggota komunitas yang rentan terhadap penularan HIV AIDS belum tentu positif terjangkit virus tersebut. Jika tes menunjukkan hasil positif, maka tentu saja pasien harus mendapatkan langkah pengobatan lebih lanjut. Alur pelayanan apabila pasien terbukti positif HIV adalah sebagai berikut :

a. Pengobatan lebih lanjut dapat dilakukan di puskesmas PDP (Perawatan Dukungan dan Pengobatan). Kota Yogyakarta memiliki empat puskesmas PDP, yakni puskesmas Gedong Tengen, Umbulharjo 1, Mantrijeron, dan juga Tegal Rejo;

b. Pasien yang berada di puskesmas PDP harus memenuhi syarat-syarat untuk dapat mengakses pengobatan ARV. Misal harus sudah melakukan 
tes rontgen, fungsi hati, dan fungsi ginjal. Hal ini penting dilakukan karena pengobatan ARV memiliki dosis tinggi dengan intensitas diminum sehari 2x setiap 12 jam dan dilakukan seumur hidup. Pengobatan gratis (KTP luar DIY dikenakan biaya Rp. 22.000,00);

c. Jika sudah dapat diberikan pengobatan secara intensif, maka pasien dapat dirujuk kembali ke LSM. Berbeda dengan LSM sebelumnya (LSM Vesta khusus penjangkauan, promosi, dan edukasi).;

d. Pasien HIV positif dirujuk ke LSM Victoryplus. LSM Victoryplus sebagai mitra KPA Kota Yogyakarta memiliki tugas untuk mendampingi pasienpasien yang sudah HIV positif. Dalam LSM tersebut terdapat kelompok dukungan sebaya, yakni anggota kelompok yang sama-sama terinfeksi HIV. Harapannya, setelah berkumpul dan berdiskusi dengan orang yang terinfeksi HIV maka akan mendapatkan dukungan moril dan solusi yang lebih realistis. Pelayanan di LSM Victoryplus juga mencakup akomodasi jaminan kesehatan. Jika pasien merupakan penduduk DIY, termasuk dalam golongan tidak mampu dan tidak ikut kesertaan dalam BPJS kesehatan, maka LSM Victoryplus akan mencarikan jaminan kesehatan sosial. Jaminan kesehatan ini meliputi perawatan rawat jalan dan rawat inap;

e. Hal ini terus dilakukan sampai pasien tersebut dapat berdaya kembali baik secara kesehatan, sosial maupun ekonomi meskipun menyandang status HIV positif. Jika ternyata kondisi pasien HIV positif semakin memburuk maka pihak LSM Victoryplus kemudian dapat mencarikan dukungan bagi pasien. Pihak LSM dapat berkoordinasi dengan KPA maupun Dinas terkait untuk mencarikan solusi bersama.

Alur pelayanan tersebut dilakukan apabila pasien positif mengidap virus HIV. Namun jika hasil tes menunjukkan hasil negatif, maka pasien dapat kembali kemasyarakat namun tetap diberikan edukasi dan tetap dihimbau melakukan perilaku yang sehat. Dalam hal ini terdapat permasalahan yang cukup kompleks, dimana baik KPA Kota Yogyakarta maupun LSM tidak bisa serta merta melarang pasien yang 
hasil tesnya negatif untuk menjauhi perilaku yang menyebabkan kerentanan penyebaran virus HIV AIDS.

Misalnya, apabila profesinya merupakan pekerja sex komersial, KPA dan LSM tidak mungkin melarang mereka untuk meninggalkan pekerjaannya tanpa bisa memberikan solusi pekerjaan pengganti yang lebih layak karena hal ini juga sangat terkait dengan keberlangsungan ekonomi mereka beserta keluarganya. Dalam posisi ini, LSM hanya sebatas mengedukasi bahwa pekerjaannya mengandung tingkat resiko yang tinggi sehingga pelakunya harus mampu menjaga kesehatan dan melakukan pekerjaannya secara aman (misal dengan penggunaan kondom secara konsisten).

Terkait dengan pelayanan bagi komunitas rentan HIV AIDS dinas terkait juga memiliki peran penting dalam upaya pencegahan dan penanganan HIV AIDS. Dinas Kesehatan Kota Yogyakarta memberikan pelayanan dibidang kesehatan dan Dinas Sosial Kota Yogyakarta memberikan pelayanan dibidang sosial (panti dan akomodasi mendapatkan pelayanan jaminan kesehatan). Selain itu Dinas lainnya juga memiliki peran yang tidak kalah penting.

Misalnya dinas pariwisata dapat mempromosikan pencegahan HIV AIDS diobjek wisata. Begitu juga dengan dinas perhubungan yang berperan mempromosikan pencegahan HIV AIDS di UPT terminal yang ada di Kota Yogyakarta. Meskipun LSM Vesta dan Victroyplus memiliki tugas utama dalam proses pencegahan dan penanggulangan AIDS, namun terdapat beebrapa LSM lain yang memiliki peran yang tidak kalah pentingnya. Terdapat LSM PKBI Kota Yogyakarta dan LSM CD Bethesda yang menjangkau usia remaja sekolah. LSM Kebaya untuk penjangkauan waria dan juga memiliki shelter/panti ODA yang anggaran operasionalnya berasal dari Dinas Sosial Kota Yogyakarta dan dapat difungsikan sebagai tempat tinggal/penampungan bagi ODA yang memang tidak memiliki keluarga atau ditelantarkan oleh keluarganya.

Dalam melakukan pelayanan penanggulangan HIV AIDS, KPA juga bekerja sama dengan masyarakat dengan membentuk komunitas warga peduli AIDS (WPA). Satu kelurahan akan mendapatkan enam warga peduli AIDS (WPA). Mereka dilatih 
dan diberikan informasi tentang HIV secara lengkap. Enam WPA yang berada dalam satu kelurahan tersebut juga dapat menjadi pengurus yang memiliki struktur mulai dari ketua WPA, wakil ketua, bendahara dan beberapa seksi terkait. WPA memiliki tugas diantaranya :

a. Pertama adalah menyebarluaskan informasi mengenai bahaya HIV melalui forum-forum dimasyarakat. Mencakup informasi dasar, perbedaan HIV dan AIDS, cara penularannya, cara pencegahannya, hal-hal apa saja yang tidak menularkan, dan yang terakhir layanannya ada dimana saja;

b. Kedua menggali potensi resiko diwilayah kerja masing-masing;

c. Ketiga, setelah menggali potensi resiko dimasyarakat tugas selanjutnya adalah merujuk pelayanan kesehatan melakukan tes HIV.

d. Keempat, tugas dari WPA adalah menjaga lingkungan tetap kondusif apabilany didaerahnya terdapat orang dengan HIV AIDS (ODHA). Tidak boleh ada stigma buruk, tidak boleh ada diskriminasi, pengusiran, dan sebagainya.

Berdasarkan penjelasan diatas, dapat disimpulkan bahwa KPA memiliki tugas adalah mengkoordinir dan melatih lembaga-lembaga atau masyarakat yang memiliki peran. Mulai dari LSM, OPD, hingga WPA. Pertemuan koordinasi rutin semua anggota KPA dilakukan setiap tiga bulan sekali. Jadi setiap tiga bulan sekali mengumpulkan anggota-anggota KPA dan tim pendukung lainnya dari OPD, LSM dan WPA. Koordinasi pertama dilakukan dengan OPD dan LSM untuk bisa nanti saling sharing kegiatan dan sebagainya. Koordinasi kedua dilakukan dengan WPA terkait laporan dan kendala dilapangan. Koordinasi ketiga dilakukan dengan membahas monitoring dan evaluasi layanan kesehatan yang sudah diberikan.

Berdasarkan dari Dinas Kesehatan Kota Yogyakarta diketahui bahwa Kasus HIV ditemukan pertama kali tahun 2004. Selama tahun 2017, tepatnya sampai dengan Oktober 2017 terdapat 1.051 kasus HIV dan AIDS. Dari 1.051 kasus tersebut, 261 diantaranya sudah masuk ke stadium AIDS. Penderita laki-laki sebanyak 67\% dan $37 \%$ sisanya diderita oleh perempuan. Faktor resiko terbesar, yakni sebanyak 
58\% adalah melalui hubungan heteroseksual, jadi hubungan sex laki-laki dan perempuan. Urutan kedua hubungan homoseksual, dan ketiga pecandu narkotika suntik. Jika diklasifikasikan berdasarkan golongan umur pada umumnya masih diusia produktif yakni usia 20-29. Merujuk pada hasil penelitian Mia Auliani (2016) mengenai strategi pelayanan HIV AIDS mulai dari sosialisasi, layanan komunikasi publik, dan kordinasi yang dilakukan KPA Kota Surakarta telah berjalan dengan baik dan melalui program-program yang terencana dan terarah, sumber daya pemberi pelayanan dan sistem pelayanan sudah cukup baik. Pihak KPA juga selalu berusaha untuk meminimalisasi dengan merespon apa yang menjadi keluhan-keluhan dari masyarakat melalui sistem pengaduan yang telah disediakan, sehingga pelayanan kesehatan yang diberikan sesuai dengan apa yang diharapkan oleh masyarakat. Hal tersebut juga yang semakin giat dilakukan oleh KPA Kota Yogyakarta guna mengungkap kasus HIV AIDS yang selama ini belum teridentifikasi.

Tren peningkatan HIV AIDS yang terjadi saat ini seperti fenomena gunung es. Kasus HIV AIDS yang ditemukan di Kota Yogakarta saat ini baru yang tampak dipermukaan saja. Besar kemungkinan masih banyak kasus yang belum terdeteksi dan terungkap. Hal ini dapat dianalisa dari semakin banyaknya penjadawalan dan permintaan kegiatan sosialisasi HIV dan semakin banyaknya layanan kesehatan yang dibuka. Dengan semakin meningkatnya kedua hal tersebut, semakin banyak pula kelompok masyarakat yang masuk dalam kelompok rentan yang sebelumnya tidak memahami bahaya HIV AIDS menjadi penasaran dan akhirnya peduli serta memeriksakan dirinya melalui layanan kesehatan. Hal ini berbeda dengan pola dimasa lalu. KPA Kota Yogyakarta beserta mitra semakin aktif mengidentifikasi gejala awal dengan cara menemukan kasus sebanyak-banyaknya dengan tetap menggunakan motto TOP (Temukan kasus, Obati, dan Pertahankan).

Sejarah pembentukan Komisi Penanggulangan AIDS diawali melalui Perpres No 75 Tahun 2005. Namun sejak tahun 2017 perpres No 75 Tahun 2005 direvisi menjadi perpres No 124 Tahun 2017 yang juga turut mengatur tentang perubahan struktur organisasi di KPA nasional. KPA nasional yang semula menjadi organisasi independen dan lembaga koordinatif yang mengkoordinasikan OPD-OPD maupun 
LSM dan pihak lain yang bergerak menanggulangi HIV AIDS, terhitung sejak tahun 2017 berubah menjadi dibawah kewenangan Kementerian Kesehatan.

Perubahan tersebut tentu saja memberikan beberapa dampak. Perubahan tersebut tentu akan merubah struktur organisasi KPA Nasional. Sebagai contoh, sekretaris yang awalnya adalah sebagai kepala tertinggi dari sekretariat KPAN dan bersifat fulltime, sekarang kemudian digantikan oleh Direktur Jenderal (Dirjen) Pencegahan dan Pengendalian Penyakit (P2P) di Kementerian Kesehatan. Kebijakan ini juga berlaku bagi KPA yang ada di daerah, mulai dari tingkat provinsi maupun kabupaten/kota mulai tahun 2018. Pada tahun 2017 ini pelaksaan tugas pokok fungsi masih menjadi tanggung jawab sekretaris KPA Kota Yogyakarta secara fulltime. Tugas pelayanan yang diberikan masih meliputi tugas koordinasi, pendataan, penyuluhan, dan juga rekomendasi pengobatan kepada UPT Dinas Kesehatan ataupun LSM yang menangani pasien HIV AIDS.

\section{PENUTUP}

Berdasarkan pembahasan diatas dapat disimpulkan bahwa manajamen pelayanan publik yang diterapkan di KPA Kota Yogyakarta lebih bersifat pelayanan tidak langsung dan koordinatif. KPA fokus pada memaksimalkan peran OPD, LSM, dan masyarakat guna menjangkau kelompok masyarakat yang rentan terinfeksi virus HIV AIDS. Langkah ini dinilai efektif ditandai dengan banyaknya kegiatan yang dilakukan dan prestasi yang diraih oleh KPA Kota Yogyakarta yang mampu mengidentifikasi penderita HIV dari tahap awal.

Saran yang dapat diberikan penulis dalam penelitian ini antara lain :

1. Pemerintah Kota Yogyakarta, khususnya KPA dan dinas terkait harus tetap konsisten menjalankan dan meningkatkan luas cakupan program penanggulangan HIV AIDS dengan tidak hanya berfokus pada daerah rawan saja, namun juga selalu meng-update potensi daerah/kelompok rawan lainnya yang semakin berkembang dari waktu ke waktu;

2. KPA Kota Yogyakarta dan para WPA harus selalu bersinergi dalam melakukan upaya sosialisasi, identifikasi masalah HIV AIDS, dan 
menciptakan suasana konduif bagi para ODA dan masayarakat umum yang ada di wilayah Kota Yogyakarta;

3. Melakukan peningkatan upaya kerjasama antara pemerintah Kota Yogyakarta dan para akademisi dalam hal kajian-kajian ilmiah lintas bidang ilmu yang terkait dengan manajemen penanggulangan HIV AIDS.

\section{DAFTAR PUSTAKA}

Harbani, Pasolong. 2013.Teori Administrasi Publik. Alfabeta. Bandung Hardiansyah .2011. Kualitas Pelayanan Publik. Yogyakarta: Gava Media.

Idrus, Muhammad.2009. metode penelitian ilmu sosial , pendekatan kualitatif dan. Kuantitatif Edisi Kedua. Jakarta : Erlangga.

Istighfarotur, Rahmaniyah. 2010. Pendidikan Etika Konsep Jiwa dan Etika Prespektif Ibnu Maskawaih. Aditya Media : Malang.

Ratminto \& Atik Septi Winarsih. 2005. Manajemen Pelayanan. Yogyakarta : Pustaka Pelajar

Ratna, Nyoman Kutha. 2010. Metodologi Penelitian: Kajian Budaya dan Ilmu. Sosial Humaniora Pada Umumnya. Yogyakarta : Pustaka Pelajar

Sugiyono. 2012. Metode Penelitian Kuantitatif Kualitatif dan R\&D. Bandung: Alfabeta.

Sugiyono. 2013. Metode Penelitian Pendidikan (Pendekatan Kuantitatif, Kualitatif, dan R\&D).Bandung : Alfabeta

Sugiyono.2009. Metode Penelitian Bisnis (Pendekatan Kuantitatif, Kualitatif, dan R\&D). Bandung: Alfabeta.

Terry, George dan Leslie W. Rue. 2010. Dasar-Dasar Manajemen. Jakarta: PT Bumi Aksara

Widyanto, F. C dan Triwibowo, C. 2013. Trend Disease Trend Penyakit Saat Ini. Jakarta: Trans Info Media

Wijayanti, Irine Diana Sari. 2008. Manajemen. Yogyakarta:Mitra Cendikia. 
Auliani, Mia 2017. Strategi Komisi Penanggulangan Aids (Kpa) Dalam Pencegahan Hiv/Aids Di Kota Samarinda. eJournal Administrasi Negara, Volume 5 , Nomor 1, 2017: 5293 - 5306 ISSN 0000-0000.

Irwanto, Joko. 2010. Manajemen Pelayanan Penanggulangan Hiv/Aids Pada Komisi Penanggulangan Aids (KPA) Kota Surakarta. Skripsi Pada Jurusan Ilmu Administrasi Negara Universitas Sebelas Maret.

Depkes RI, 2009. Sistem Kesehatan Nasional. Jakarta.

Republika.co.id (2015). Jumlah Pengidap HIV/AIDS di Yogya Terus Meningkat. $\begin{array}{llllll}\text { Diperoleh } & \text { tanggal } & 3 & \text { Agustus } & 2017 & \text { dari }\end{array}$ http://nasional.republika.co.id/berita/nasional/daerah/15/11/10/nxk67k346jumlah-pengidap-hivaids-di-yogya-terus-meningkat

Spiritia.or.id (2016). Laporan Situasi Perkembangan HIV/AIDS dan PIMS s.d. Desember 2016. Diperoleh tanggal 3 Agustus 2017 dari. http://spiritia.or.id/Stats/detailstat.php?no=8 